\section{Reorientasi Nilai-Nilai Sekolah dalam Lintas Sejarah Manusia}

\section{Imam Hanafi}

Nafie_ihsan@yahoo.co.id

\section{Abstract}

Reorientasi Nilai-Nilai Sekolah dalam Lintas Sejarah Manusia: Sekolah seringkali menjadi "hantu" bagi sebagian peserta didik. Karena perlakuannya yang terkadang melupakan aspek-aspek nilai dan spritualitas peserta didike itu sendri. Tulisan ini, merupakan hasil tela'ahan terhadap nestapa itu dan sekaligus melihat alternative lain dengan mengajukan spritualitas dan batiniah peserta didik sebagai basis pengembangan pendidikan.

Keywords: Nilai, Sekolah Sejarah Manusia.

\section{Pendahuluan}

Baik kemarin hingga sampai saat ini, kita masih meyakini sebuah misi ; bahwa melalui pendidikan sekolah kita telah menciptakan arah baru dalam sejarah kebangkitan manusia. Meskipun tindakan mendidik dan pendidikan, bisa saja terjadi dimana saja, dilakukan oleh siapa saja, dan bisa mengenai apa saja. Tindakan pendidikan seperti ini bisa kita lihat misalnya dalam relasi orang tua dan anaknya. Setiap kegiatan yang mereka lakukan baik besar maupun kecil, selalu mengandung arti mendidik.

Kekhasan sekolah sebagai lembaga pendidikan ini adalah bahwa dirinya melakukan tindakan pendidikan secara sadar, dan seluruh aktifitasnya ditujukan untuk intensitas dalam melakukan proses pendidikan. sementara itu tindakan pendidikan diluar sekolah masih bersifat aksidental. Sehingga, yang menjadi dasar yang sangat fundamental terhadap keberadaan sekolah ini adalah intensitas dan oroginal motivation-nya untuk melakukan "rekontruksi" mendidik. Kesadaran, intensitas, dan original motivation mendidik inilah yang menuntut sekolah untuk terus menerus merefleksikan keberadaannya kearah yang lebih qualifaid.

Oleh karena itu, pemikir seperti almarhum Ernest Gellner (1983) melihat sekolah sebagai cara untuk mensosialisasikan ("mendidikkan") kepada generasi baru tentang isi kebijakan, ketrampilan, dan cara bertindak yang akan dibutuhkan untuk suatu komunitas politik, ekonomi dan kultur tertentu. Bahkan secara lebih jauh pendidikan di sekolah, sebagaimana yang disebut oleh A. Syafi'i Ma'arif, sesungguhnya juga wahana paling efektif untuk internalisasi nilai-nilai demokrasi, pluralisme, dan inklusifisme. Nah, disinilah sekolah diharapkan mampu "menebus" cita-cita ideal tersebut, menjadi sebuah realitas yang riil, yang mampu memberikan sumbangan bagi peradaban manusia.

Akan tetapi, sekolah sering kali menjadi sebuah "penjara" yang membelenggu kreatifitas peserta didik. Apa bedanya sekolah dengan penjara jika ruang-ruang kelas lebih mirip dengan kerangkeng ; ketika pelajaran dimulai lalu pintu ditutup rapat-rapat, bangku-bangku semakin memaku tubuh para siswa untuk bergerak bebas, dan lebihlebih jika Gurunya mirip seorang sipir penjara, marah jika dikritik, menolak jika ada usulan, membentak jika ada kesalahan, bahkan memukul ketika ada yang pantas dipukul.

Oleh karena itu, perlu dilakukan pemaknaan ulang terhadap sekolah sebagai sebuah "transformator" bagi peserta didik yang menyimpan berbagai keunikan sebagai manusia. Makalah ini mencoba membahas persoalan sekolah, yang menjadi bagian penting dalam sejarah kehidupan manusia itu sendiri.

\section{Makna Sekolah ; Tinjauan Sejarah}

Sekolah dalam bahasa Latin adalah skbole, scole, scolae, atau schola, yang berarti "waktu luang" atau "waktu senggang".1 Kata ini,

${ }^{1}$ Roem Topatimasang, Sekolah Itu Candu, (Yokyakarta : Pustaka Pelajar. 1998), hlm. 5 - 6. 
kemudian berkembang menjadi kata school atau Sekolah dalam bahasa kita. Secara historis, dulu masyarakat Yunani jika mengisi waktu luang, dengan cara mengunjungi sebuah tempat atau ke tempat orang pandai untuk mempertanyakan dan mempelajari sesuatu yang menurut mereka memang sangat perlu untuk diketahui. Sehingga kegiatan ini mereka sebut dengan istilah-istilah tersebut, yang artinya sama dengan "waktu luang yang digunakan secara khusus untuk belajar (Leisure devoted to learning)". Dari kebiasaan mengisi waktu tersebut, lama kelamaan menjadi tradisi putra-putri mereka, bukan milik lelaki dewasa atau sang Ayah. Hal ini, kemudian di dukung dengan tuntutan perkembangan hidup yang kian menyita waktu, di mana orang tua merasa tidak mempuyai waktu untuk mengajarkan banyak hal kepada putra-putrinya. Oleh karena itu, mereka kemudian mengisi waktu luang anak-anak dengan cara menyerahkan kepada seseorang yang dianggap tahu atau pandai disuatu tempat tertentu, yang biasanya di tempat dimana mereka juga pernah ber-skhole. Ditempat inilah, mereka belajar banyak hal, bermain dan berlatih melakukan sesuatu.

Maka sejak saat itu, tempat ini kemudian beralih fungsi sebagai scola matterna (pengasuhan ibu sampai usia tertentu), yang merupakan proses dan lembaga sosialisasi paling tua dalam sejarah umat manusia, menjadi scola in loco parentis (lembaga pengasuhan anak pada waktu luang di luar rumah, sebagai pengganti ayah dan ibu). ${ }^{2} \mathrm{Hal}$ ini pulalah yang menjadikan tempat ini, kemudian disebut sebgai lembaga pengasuhan atau "ibu asuh" atau "ibu yang memberikan ilmu (alma mater).

Tradisi ber-skhole ini, jauh sebelum Socrates dan Plato menyelenggarakan Academia atau Lyceum di Athena, konon juga pernah ada di Cina Purba yaitu 2000 tahun sebelum masehi. Dan ini dianggap lembaga sekolah tertua yang pernahada didunia. Di India, yang

${ }^{2}$ Ibid. hlm. 7. dipeolopori oleh kaum Brahma juga pernah membangun sekolahsekolah Veda setengah abad sesudahnya. ${ }^{3}$

John Amos Comenus dengan karyanya Didactica Magna, mencoba menguraikan pelembagaan pola dan proses pengasuhan anak-anak itu secara sistematis dan metodis, terutama ketika dihadapkan pada problem keragaman kultur dan proses perkembangan anak yang berbeda, tentunya membutuhkan penanganan yang berbeda pula. Buku ini kemudian diteruskan oleh Johann Heinrich Pestalozzi pada abad ke-18, dengan uraian yang lebih rinci. Dia menjelaskan tentang pola asuh dan pengelompokaan anakanak asuhannya secara berjenjang, termasuk pada perjenjangan urutan kegiatan ("pelajaran") yang musti mereka lalui secara bertahap. Sistem ini kemudian dikenal dengan "Sistem Klasikal Pestalozzi", yang kemudian menjadi cikal-bakal pola pembelajaran sekolah-sekolah modern yang kita kenal hingga saat ini dengan penjenjangan kelas dan tingkatannya.

Nah, dari konteks kesejarahan ini, dapat kita telusuri bahwa Sekolah hanyalah sebuah tempat yang dijadikan sebagai pengisian waktu luang. Akan tetapi sekarang, makna Sekolah diartikan sebagai Hakikat Pendidikan itu sendiri. Seharusnya, sekolah dipahami dalam konteks kesejarahannya sebagai sebuah bagian dari keseluruhan peradaban manusia. Sehingga sekolah yang ada saat ini, hanyalah merupakan sebuah hasil dari perjalanan panjang dimasa lalu. Karenanya, bisa jadi arah dan model ber-skhole pun akan sangat berbeda seiring dengan perkembangan peradaban manusia itu sendiri.

Lihatlah misalnya, Sekolah bisa diartikan sebagai sebuah "paguyuban" para pakar. "Sekolah Frankfurt" sebuah paguyuban ilmiah para pakar sosiologi aliran Max Horkheimer dan Jurgen Habermas, yang mempunyai pengaruh besar pada pemikiranpemikiran pada saat ini. Lalu "Sekolah Wina" yang dirintis oleh pakar

3 Lihat Education dalam Encyclopedia Amiricana, (Danbury : Grollier International. 1982) hlm. 642 - 657. Lihat juga Education dalam Encyclopedia of Social Science. (London : MacMillan. 1983) hlm. 509 - 539. 
Psiko-Analisa Alferd Adler. Juga "Sekolah Durkheim", sebuah "sekolah" dari pemikir besar ilmu sosiologi. Yang terakhir ini, Sekolah berubah makna menjadi suatu "aliran Pemikiran (School of Thought)" dari tokoh-tokoh besar pemikir dunia.

Bagi kita, yang sudah memahami sekolah sebagai sebuah institusi yang mencoba membangun kesadaran untuk berkembang atau yang lainnya, tentu akan sulit jika sekolah berbeda dengan pengertian yang kita miliki. Karena pada dasarnya sekolah bukanlah satu-satunya media Pendidikan manusia. Sekolah hanyalah sebagai tempat "persinggahan sementara" anak-anak manusia dalam melihat realitas sesungguhnya, bukan malah menutup diri dengan realitas disekitarnya.

\section{Sekolah dan Dilema Kemanusiaan}

Ketika Sekolah dihadapkan pada perkembangan globalisasi, yang mengharuskan sesorang untuk berinteraksi dengan perkembangan ilmu dan teknologi, maka sekolah semakin dipertanyakan relevansinya jika dikaitkan dengan kontribusinya bagi pembentukan budaya modern. Di sinilah lalu sekolah mengalami degradasi fungsional, karena pelan-pelan ia berorientasi pada matrealistik. Sekolah cenderung disiapkan sebagai asset sosial yang mempunyai fungsi khusus dalam menyiapkan tenaga kerja, yang akan memenuhi tuntutan dunia kerja yang bercorak industrialistik. Sehingga yang menjadi basis akurasi penilaian program suatu sekolah adalah seberapa jauh out put sekolah tersebut dapat berpartisipasi aktif dalam mengisi lapangan kerja, yang memang telah disiapkan oleh dunia industri.

Dalam konteks ini, sekolah justru semakin terkapar dengan tuntunya sendiri, dimana "komoditi" yang dihasilkan selalu kalah berpacu dengan "idealisme" sekolah, karena dorongan dan tuntutan perkembangan masyarakat. Sementara, perkembangan teknologi dan informasi kini mempunyai kaitan yang sangat erat dengan perkembangan norma dan tata nilai kemanusiaan. ${ }^{4}$ Misalnya, pola-pola interaksi dan komunikasi sosial kemasyarakat akan menunjukkan gejala pragmatisme, hedonisme, dan lain sebagainya. Disinilah lalu sekolah menjadi satu kesatuan dengan sistem sosial.

Jika sekolah menjadi salah satu unit dari sebuah sistem sosial, maka biasanya ia dikungkung dengan berbagai aturan dan kebijakan yang tidak memungkinkan lahirnya sekolah yang adaptif dan fleksibel terhadap perkembangan lingkungan sosial sekitarnya. Maka lahirlah istilah "penganggur terdidik", karena tidak ada kesediaan lapangan kerja yang relevan dengan keahlian yang mereka miliki. Juga karena tidak adanya daya adaptabilitas untuk melakukan modifikasi sikap terhadap dunia kerja.

Kondisi ini menjadi semakin memprihatinkan, pada saat sekolah mengalami alih fungsi menjadi sekedar "pemasok" tenaga kerja terampil yang dibutuhkan oleh dunia kerja. Meskipun sebenarnya, itu juga menjadi sisi penting untuk "menyelamatkan" peserta didik dimasa depannya, tetapi fungsi yang lebih penting adalah sebagai penyebar dan dinamisasi nila-nilai kemanusaiaan, yang dapat menyadarkan manusia tentang hakikat eksistensinya di tengah perkembangan dan tantangan di masyarakat. ${ }^{5}$

Bagi Muhamat Hatta, sekolah harus mampu memberikan pola pendidikan karakter atau watak, yang mampu memberikan makna bagi manusia dalam pergaulannya dengan sesama, yang adil dan sejahtera. Oleh karenanya proses pembelajaran di sekolah harus mempunyai nuansa "pendidikan" bukan "pengajaran". Kata Hatta "Pendidikan terletak dimuka, pengajaran di belakang. Pendidikan membentuk

${ }^{4}$ Untuk melihat secara detail mengenai kaitan ini, lihat tulisan Sudjatmoko, "Pembangunan Sebagai Proses Belajar" dalam Sudjatmoko dkk, Masalab Sosial Budaya Tabun 2000. (Yogyakarta : Tiara Wacana. 1986).

${ }^{5}$ M. Rusli Karim, "Pendidikan Islam di Indonesia Dalam Transformasi Sosial Budaya" dalam Syafi'i Ma'arif dkk, Pendidikan Islam di Indonesia ; Antara Cita dan Fakta. (Yogyakarta : Tiara Wacana. 1991) hlm. 128 - 129. 
karakter, pengajaran memberikan pengetahuan yang dapat digunakan dengan baik oleh anak-anak yang mempunyai karakter". ${ }^{6}$

Sementara Antony Gidden, mencoba menjelaskan bahwa pendidikan sekolah telah meningkatkan ketidak adilan kemanusian. Menurutnya bahwa memang pendidikan mempunyai hubungan yang komplek dengan pemerataan, tetapi sering pendidikan justru menghasilkan ketidak adilan dan mempertajamnya. Misalnya, semakin dia tidak mampu bersekolah maka semakin dia tidak mendapat "posisi" yang layak di masyarakat. Meskipun demikian, Gidden menyebut aspek politik sangat berpengaruh dalam persoalan ketidakadilan ini.

Persoalan lainya adalah ketika sekolah tidak pernah melihat bagaiman kondisi batin peserta didiknya. Padahal manusia tidak mungkin terlepas dari hidup batinnya. Entah disadari atau tidak, setiap pribadi mempunyai pengalaman batin dalam setiap kondisi hidupnya. Penolakan terhadap situasi batin ini justru akan melahirkan hidup yang tidak utuh, pribadi yang pecah. Proses menjadi dewasa adalah proses menerima dan mengolah pengalaman-pengalaman batin ini. Sementara pengenalan dan penerimaan dunia batin dalam hidup, akan melahirkan peace of mind (ketenangan hidup). Bentuk ketenangan ini penting untuk sebuah penemuan kreativitas. Sebab, pribadi yang kreatif adalah pribadi yang berani berhadapan dengan diri sendiri dan berani melakukan penjelajahan. Ini bisa dilakukan ketika seseorang itu berjiwa tenang dan reflektif, bukan pribadi yang tergesa-gesa dan ada dalam tekanan.

Kemampuan Batin, menurut Howard Gadner, penggagas teori multiple intelligences, adalah kemampuan seseorang untuk mengenali dan mengolah pengalaman-pengalaman batiniahnya (internal experiences). Menurutnya jika peserta didik mempunyai kecerdasan ini, maka ia akan mampu bertahan dan menghadapi kondisi kelemahan diri

6 Di kutip dari Tulisan Sindhunata, "Pendidikan Meningkatkan Ketidakadilan" dalam Kompas, No. 07 - 08, Tahun ke-51, Juli - Agustus 2002. hlm. manusiawinya secara dewasa, dan mampu memberika inspirasi kepada orang-orang disekitarnya.

Ada beberapa hal, kenapa sekolah saat ini melupakan sisi batin ini ; Pertama, sistem sekolah yang bersifat klasikal, memberikan suasana kelas kurang hidup, kurang menghidupkan relasi yang sifatnya personal, relasi antar pribadi. Pada sistem ini, tidak ada komunikasi antar individu, yang ada hanyalah sebatas komunikasi akademik. Kedua, terbatasnya figur yang bisa dijadikan tempat mengkomunikasikan pengalaman-pengalaman tersebut. Ketiga, karena memang tidak adanya sistem yang mencoba mengajak peserta didik untuk mengenali, merefleksi dan mengungkapkan pengalaman batinnya.

Sementara itu, sudah menjadi opini di setiap orang bahwa sekolah diharapkan mampu mengubah manusia, dari yang tidak bisa menjadi bisa, dari tidak mampu menjadi mampu, dari yang tidak berbudaya menjadi berbudaya. Dengan kata lain, melalui sekolah, setiap orang akan menjadi manusia yang siap, cakap, mumpuni, dan sukses dalam menghadapi masa depan. Nah, harapan yang begitu besar terhadap sekolah, jika dikaitkan dengan persoalan diatas, menuntut sekolah untuk lebih menekankan proses pendidikan bukan pengajaran. Akan tetapi problemnya adalah apakah sekolah mampu mengubah itu semua, meskipun dengan berbagai model, bentuk dan lainnya, jika sekolah hanya "menangani" peserta didik selama sekitar tujuh jam setiap hari, selama enam hari?

\section{Reorientasi Sekolah ; Sebuah Pencarian}

Tujuan sekolah disetiap jenjangnya, pada hakikatnya adalah meningkatkan pengetahuan siswa untuk melanjutkan pendidikan pada jenjang yang lebih tinggi dan mengembangkan diri sejalan dengan perkembangan ilmu pengetahuan, teknologi, kesenian, dan meningkatkan kemampuan peserta didik sebagai anggota masyarakat 
dalam mengadakan hubungan timbal balik dengan lingkungan sosial, budaya, dan sekitarnya. ${ }^{7}$

Kata kunci yang menarik untuk dicermati dari rumusan diatas adalah "mengembangkan diri". Pertanyaannya reflektifnya adalah betulkah Sekolah dalam praksisnya telah mampu mengembangkan diri para peserta didik atau justru sebaliknya, yang terjadi adalah "membunuh" mereka secara dini? Dimana materi-materi pelajaran di "sesakkan" sedemikian rupa ke otak-otak peserta didik. Kesadaran untuk maju dicoba melalui media pengembangan dan pola-pola penciptaan keresahan, ancaman, dan bahkan hukuman oleh guru.

Sekolah, pada akhirnya telah kehilangan ruh kanalisasi diri, etos kesepahaman, ekspresi dan aktualisasi pemikiran. Kesenangan pada proses pembelajaran, berubah "drastis" menjadi kebingungan, kenyamanan belajar pada akhirnya tidak lagi ditemukan di kelas. Inilah yang menjadi kegelisahan oleh para pemikir pendidikan, Kurt Singger menyebutnya sebagai "Pedagogi hitam". Sinisme senada juga muncul dari Ivan Illich, yang menyuarakan proyek "deschooling sociaty" (masyarakat bebas dari sekolah). Kemudian Everett Reimer, meneriakkan "the end of school", Paulo Friere dengan "pedagogy of the opressed"-nya, serta "the end of education" dari 'celotehan' Neill Postman.

Setidaknya ada empat orientasi dan idealisme pendidikan dalam melakukan "rekontruksi" mendidik itu, Pertama, perolehan pengetahuan dan kemampuan (kompetensi). Orientasinya, menekankan pada perolehan pengetahuan dan kemampuan untuk mempersiapkan peserta didik mendapatkan kesempatan kerja. Dalam konteks ini, upaya pendidikan difokuskan pada perolehan pengetahuan dan ketrampilan khusus supaya unggul dalam bidang tertentu. Tolak ukurnya, sejauhmana peserta didik mampu menemukan lapangan kerja dengan tingkat pendidikannya. Dalam arti tertentu pendidikan diarahkan untuk memberi sumbangan bagi penyelenggaraan kesejahteraan masyarakat setempat dengan

7 Paul Suparno, dkk, Reformasi Pendidikan; Sebuah Rekomendasi,. (Yogyakarta : Kanisius. 2002), hlm. 67 mempersiapkan peserta didik masuk kelapangan kerja. Memperoleh ketrampilan dan pengetahuan ini biasanya menjadi tujuan yang dominan peserta didik dalam memilih sekolah atau perguruan tinggi tertentu.

Kedua, orientasi humanistik. Dalam konteks ini, pendidikan diarahkan pada usaha pengembangan kemampuan penalaran, kemampuan untuk mempertanggungjawabkan pernyataanpernyataannya, keyakinan-keyakinannya, dan tindakan-tindakannya. Tujuan lainnya, yaitu agar mampu memahami "apa" dan "mengapa" dari apa yang dipelajari serta meningkatkan kemampuan mengorganisir pengalaman dalam konsep-konsep yang sistematis. Dengan demikian, orientasi pendidikannya adalah proses pembentukan disposisi dasariah peserta didik dan kemampuan intelektual serta emosional dalam hubungannya dengan sesama, lingkungan, dan alam. Tolak ukurnya, (1), Minat membaca dan kemampuan untuk mengerti dan memahami apa yang dibaca. Ketrampilan ini ditunjukkan pada kesanggupan untuk mengemukakan suatu gagasan dengan teratur dan logis sebagai sarana mempertanggungjawabkannya secara argumentative. (2), Kesanggupan untuk menangkap pikiran orang lain dengan tepat dan menanggapinya secara terbuka dan kritis. (3), Kebiasaan untuk mempelajari secara sistematis apa yang dilakukan dan mulai mengadakan studi terbatas yang sesuai dengan tuntutan lingkungan, sebagai landasan pembentukan pendapat sendiri.

Ketiga, Menjawab tantangan sosial, ekonomi, dan keadilan. Dalam perspektif ini, pendidikan diarahkan untuk menyiapkan peserta didik dalam mengenali dan menjelaskan masalah-masalah yang dihadapi masyarakat dan kemudian menghasilkan jawaban-jawaban berdasarkan pada etika sosial. Merujuk pada Paulo Freire (Pedagogy of The Opressed) bahwa pendidikan adalah pelibatan politik, maka peserta didik diarahkan pada kemampuan untuk berkembang menjadi warga negara yang memiliki ketrampilan dalam mengolah proses-proses sosial, memiliki komitmen pada nilai-nilai demokratis, yaitu mampu berpartisipasi didalam proses sosial, politik, dan ekonomi. Oleh karena 
itu, perolehan pengetahuannya diperuntukkan pada pelayanan perkembangan manusia dan kesejahteraan masyarakatnya. Tolak ukurnya adalah tumbuhnya minat memahami secara kritis perubahanperubahan yang sedang berlangsung di masyarakat. Pendidikan tidak membuat peserta didik terasing dari cara hidup lingkungannya yang secara ekonomi, sosial, dan politik lebih rendah, sehingga peserta didik menjadi peduli terhadap masalah-masalah ketidakadilan, peka terhadap penderitaan, kebutuhan, dan aspirasi masyarakat.

Dan Keempat, Peran sosial pendidik. Di sini, guru atau pendidik mempunyai peran sentral dalam mengembangkan tiga hal diatas. Guru tidak lagi menjadi alat penguasa untuk melegitimasi politik penguasa. Melainkan secara aktif dan kreatif mengembangkan diri sesuai dengan kebutuhan sosial-kemasyarakatan daerah masing-masing. Ada tiga model untuk memberikan penjelasan tentang orientasi pendidikan ini. Pertama, metode tradisional. Model ini, ditandai dengan pembelajaran berhadapan (one man one show) yakni kritik pendidik berhadapan langsung dalam satu ruang. Perhatian, ingatan, dan penalaran menjadi sarana pembelajaran utama dalam metode ini. Diaolog antara peserta didik dengan pendidik hanya sekedar berupa pertanyaan-pertanyaan dan jawaban-jawaban. System evaluasi yang dipakai biasanya mengikuti klasifikasi dan atas dasar jasa atau prestasi, dan didasarkan pada otoritas pendidik. Kedua, Aktif. Dan Ketiga, Aktual. Keduanya mempunyai konsepsi yang sama tentang perkembangan yang didasarkan pada aktivitas dan kemandirian peserta didik. Metode Aktif dipengaruhi oleh beberapa aliran-aliran pendidikan baru, terutama dari Maria Montessori, Celestin Freinet, Paulo Friere, dan lainnya. Aliran in, mengacu pada dasar teoritis kritik Humanis (Rabelais), filsafat kontruksi subyek (Rousseau dan John Dewey), dan sumbangan dari psikologi perkembangan (Piaget) serta psikologi humanis (Rodgers). Kedua model ini, sangat menekankan nilai, kreatifitas, aktifitas, dan afektifitas yang kesemuanya teraktualisasi pada proses pembelajan.
Orientasi diatas, lebih menekankan pada pendekatan indrawi dan rasionalitas, yang kemudian bermuara pada pengkayaan aspek materi. ${ }^{8}$ Oleh karena itu, sekolah perlu merambah pada proses pengetahuan yang berbasis pada pengetahuan metafisika, selain yang bersifat fisik. Tuhan dalam kaca mata Imanuel Kant misalnya, hanya bisa diketahui dengan melalui argumen moralitas (practical reason, akal praksis) bukan melalui penalaran kritis-analisis (akal murni, pure reason). ${ }^{9}$ Dalam Islam, pengalaman yang mampu melahirkan prinsip-prinsip etika adalah dengan melalui "hati nurani", ${ }^{10}$ yaitu dengan melalui cara mengasah hati (riyadhah), ${ }^{11}$ agar dapat merasakan dan menangkap pengetahuan

${ }^{8}$ M. Quraish Shihab, Wawasan al-Qur'an ; Tafsir Maudhu'i Atas Berbagai Persoalan Umat, (Bandung : Mizan. 1996), hlm 63.

9 Lihat kajian M. Amin Abdullah dalam disertasinya yang membahas tentang filsafat etika Imanual Kant ini, khususnya pada Bab II, sub A. "Kant's Critique of Pure Reason". M. Amin Abdullah. The Idea of Universality of Ethical Norms in Ghazali and Kant (Ankara : Turkiye Diyanet Vakfi Yayinlari, 1992) hlm 47 -51 .

10 Istilah "hati nurani" ini sebenarnya mengandung makna yang sangat esensial, yaitu esensi kebaikan yang disebabkan oleh sesuatu dalam diri manusia yang bersifat cahaya (nurani), yang akan membimbing seseorang kearah kebaikan. Ini adalah kelanjutan dari ayat Qur'an yang menyebutkan "Maka luruskanlah dirimu kepada agama (yang benar), mengikuti kecendrungan kepada kebenaran, sesuai dengan fithrah Allah yang telah menciptakan manusia dalam fithrah itu. Tidak boleh ada perubahan dalam sesuatu yang diciptakan (ditetapkan) Tuhan. Itulah tujuan agama yang lurus, tetapi kebanyakan manusia tidak mengetahui" (QS. al-Rum : 30). Fithra atau kejadian asal yang suci pada diri manusia itulah yang memberinya "kemampuan bawaan dari lahir dan intuisi untuk mengetahui benar salah, sejati dan palsu, dan dengan begitu akan mampu merasakan kehadiran Tuhan dan keesaan-Nya. Lebih jauh lihat Muhammad Asad. The Message of The Qur'an. (Gibraltar : Dar al-Andalus. 1980), khususnya catatan kaki nomor 27.

11 al-Syaibani membagi sumber pokok pengetauan menjadi tiga, Indera, akal, intuisi, ilmu, dan wahyu. Nah, intuisi inilah yang mampu memberikan arah baru akan sentuhan rasa dan emosi, yang akan menjadikan kita lebih cerdas dalam beriteraksi dengan sesama maupun kepada Tuhan. Omar Muhammad al-Taumi alSyaukani, Falsafah Pendidikan Islam, (tri). (Jakarta : Bulan Bintang. 1979) hlm. 271 176. 
yang terdalam. Inilah sebenarnya pengetahuan paripurna, yaitu pengetahuan mengenai Allah (dalam bahasa al-Attas Ma'rifah).

Realitas metafisis ini, bagaimanapun merupakan kajian ilmu pengetahuan yang universal. Karena ia akan berbicara tentang pengetahuan puncak, yang mencakup segala sesuatu, yang menjadikan kita kepada paradigma yang ilabiyyah, paradigma yang mengembalikan prinsip-prinsip etika pembelajaran pada Keesaan Allah. Sebuah paradigma yang menomor-satukan dimensi spritualitas, paradigma yang melatih kita untuk selalu mengasah dimensi rubaniyyah kita. Inilah, yang akan mendorong sekolah pada semangat long life education, pendidikan sepanjang masa. Karena "pencarian kepada al-Haq" pada hakikatnya adalah proses tiada henti.

Salah satu contoh dari "alumni" sekolah model ini adalah misalnya pada abad III - VII H, kreatifitas dan dinamika spritualitas telah mampu memberikan inspirasi pada pemikir-pemikir, baik dibidang filsafat, kalam, dan hukum. Tokoh-tokoh seperti al-Farabi, Ibn Sina, Ibn Bajah, Ibn Tufail, Suhrawardi, al-Ghazali, bahkan tokohtokoh ahli kimia dan fisika ; al-Iraqi, Jubir Ibn Hayyan (penggali pertama ilmu aljabar), dan al-Razi (ahli Ilmu Optik) adalah orangorang sufi. Begitu pula Nash al-Din at-Thusi dan Ibn Bana' alMarakusyi. Bahkan pendekatan spritualitas ini, telah mempengaruhi peradaban materal. Hampir setiap bentuk seni mulai puisi, sajak ceritacerita,sampai pada bentuk arsitektur ; masjid, Istana memperlihatkan keterpaduan dengan sufi. ${ }^{12}$

Dalam salah satu bukunya yang sangat fenomenal, Danah Zohar dan Ian Marshal,13 secara terbuka mengutip puisi Jalaludin al-Rumi untuk mendukung teori kecerdasan spritualnya. ${ }^{14}$ Cerdas secara spritual, merupakan kecerdasan yang berada pada bagian diri yang

12 Lihat SH. Nasr. Spritualitas dan Seni Islam. (Bandung : Mizan. 1993)

13 Danah Zohar dan Ian Marshal. SQ ; Memanfaatkean Kecerdasan Spritual dalam Berfikir Integralistik dan Holistik untuk memahami Hidup (tri). (Bandung : Mizan. 2000)

${ }^{14}$ Teks lengkapnya baca halaman 9. terdalam, kedalaman hati (deep insight), pemahaman dan kearifan berfikir. Kecerdasan spritual juga akan memberikan kesadaran yang akan mendorong kita tidak saja untuk mengakui nilai-nilai "suci" tetapi juga secara kreatif akan menemukan nilai-nilai baru. Sehingga tidak heran jika Danah Zohar dan Ian Marshal, menyebut kecerdasan ini sebagai The Ultimate Intelligensi, puncak kecerdasan.

Kecerdasan ini, justru hanya berada pada prototype manusia yang bersih secara spritual. Sehingga basisnya adalah self its self (fithrah dalam Islam) dimana ia dituntut untuk mengikuti jalur eksistensi diri yang dahulu ia berasal, "perjanjian primordial" istilahnya Nurcholis Madjidatau dalam bahasa kaum Perennialis "alam surgawi", dan karenanya pula manusia selalu berada pada kondisi (istilah penganut filsafat eksistensialisme) "the peace of the allsufficience". Dalam Islam keberadaan manusia seperti ini adalah al-Nafsu al-Muthmainnah, jiwa yang damai dan tenang, yang bisa menjalin kontak spritual dengan Ilâhi Rabbi. Dengan konsep dasar (fithrah) yang termanifestasi dalam konsep "perjanjian primordial" inilah, ${ }^{15}$ menjadi modal bagi manusia untuk menjadikan kebaikan (taubid, keesaan Tuhan) sebagai basis bagi semua prilaku manusia. ${ }^{16}$ Oleh karena itu, manusia musti berada pada kondisi "bersih" secara spritual.

Menjadikan kecerdasan sufistik, sebagai basis pembelajaran di sekolah, merupakan sebuah upaya mensintesiskan kekayaan intelektual (rasionalitas) dengan kekayaan spritual yang berbasis pada penggalian sisi batiniyyah, yang mempertautkan dimensi terdalam manusia. Tidak heran jika kemudian, Kuntowijoyo pernah merekomendasikan untuk

15 Yang dimaksud dengan "perjanjian primordial" ini adalah suatu ikatan janji yang terjadi pada zaman azali dengan Tuhan dan manusia, bahwa manusia primordial mengakui Dia sebagai Tuhan. Hal ini dapat kita lihat dalam ayat "Dan ingatlah ketika Tuhanmu mengeluarkan keturunan anak cucu Adam dari tulang selangkangan mereka, kemudian Dia meminta persaksian mereka atas diri mereka sendiri, (dan Allah berkata) "bukankah Aku adalah Tuhanmu sekalian?", mereka semua menjawab “ya, benar, kami semua menjadi saksi”..(QS. Al-A'raf : 172).

${ }^{16}$ Munzir Hitami. Mengonsep Kembali Pendidikan Islam. (Pekanbaru : Infinite. 2004) hlm $11-14$ 
memasukkan khazanah sufi kedalam pendidikan Islam. Karena Sufi telah mampu mentransendensikan hodup manusia, juga kekayaan yang terkandung didalamnya, yang sangat menekankan aspek kedalaman (deepness) manusia. ${ }^{17}$ Abdul Hadi WM, juga menegaskan perlunya memasukkan sastra-sastra sufi dalam pendidikan kita. Sebab baginya, sastra sufi mengandung semangat profetik. ${ }^{18}$ Yaitu semangat yang mendorong kita untuk selalu menyambungkan dimensi sosial (kemanusiaan) dengan dimensi transcendental (Ilabi Rabbi).

\section{Kesimpulan}

Pada dasarnya, pendidikan di Sekolah mencoba untuk mencari dan membangun sebuah transformasi, sebuah usaha yang selalu membawa klaim-klaim metodologi dari para pembawanya, agar menjadi valid dan tetap selalu dipakai disetiap zaman. Akan tetapi, hal itu harus berangkat dari pertarungan yang panjang, yang melampaui dimensi ruang, tempat dan lokalitas pemikiran seseorang. Dari proses tersebut, tentu akan selalu ada mata rantai metodologis yang pada dataran praksisnya menjadi "ideal". Yaitu manifestasi dari tesisantitesis, aksi-reaksi, dan kontruksi-rekontruksi atau dekontruksi.

Oleh karena itu, proses aktualisasi pendidikan dan pembelajaran di Sekolah akan selalu menjadi sementara (bypo-knowledge), yang pada suatu saat akan "berselingkuh" dalam bentuk beragam rupa, sesuai dengan parameter dan indikator yang mengiringinya, baik yang bersifat aksidental, lokalitas, kontekstualitas, maupun karena lemahnya

${ }^{17}$ Kuntowijoyo menyebutkan ; "Substansi sufisme seperti khauf (penuh rasa takut), Rajâ' (sangat berharap), Qonâ'ah (menerima pemberian Allah), Tawakkal ((pasrah), Syukûr, Ikblâs dan sebagainya, dapat menjadi materi pendidikan Islam". Sementara dalam pendidikan moral, dia menambahkan "kalau direct theaching tidak sesuai lagi, dan tidak examplery center yang dipercayai, maka târikh Nabi, para Shahabat, dan teladan orang-orang suci dapat dimasukkan, demikian juga sejarah, mitos dan sastra". Lihat Kuntowijoyo, "Krisis Kebudayaan ; Kesenjangan Antara Kesadaran dan Prilaku” dalam Republika, edisi Rabu 16 Desember 1998).

18 Abdul Hadi WM, "Semangat Profetik dalam Sastra Sufi dan Jejaknya dalam Sastra Modern” dalam Horison, no 6, tahun XXII, Juni 1998, hlm 184. "jari-jari” kebenaran tersebut mencengkeram suatu zaman. "Perselingkuhan" atau bahkan pertentangan sama sekali, dari satu kebenaran ke kebenaran lainnya, merupakan dialektika dan dinamika tersendiri dalam diri proses pendidikan dan pembelajaran. Wallabu a'lam bi al-Showab

\section{Bibliografi}

Abdullah,. M. Amin, The Idea of Universality of Ethical Norms in Ghazali and Kant, (Ankara: Turkiye Diyanet Vakfi Yayinlari, 1992).

al-Attas, Syed Naquib, A Commentary on The Huijat al-Sbiddiq of Nur alDin al-Raniri, (Kualalumpur: Kementrian Kebudayaan, 1986).

Intuition of Existence: A Fundamental Basis of Islamic Metaphisics, (Kualalumpur: ISTAC, 1990).

Asad, Muhammad, The Message of The Qur'an, (Gibraltar: Dar alAndalus, 1980).

Barnadib, Filsafat Pendidikan: Sistem dan Metode, (Yogyakarta: Andi Ofset, 1994).

Danah Zohar dan Ian Marshal, SQ: Memanfaatkan Kecerdasan Spritual dalam Berfikir Integralistik dan Holistik untuk memahami Hidup (tri) (Bandung : Mizan, 2000).

Danusiri, Epistemologi dalam Tasawnf Iqbal, (Yogyakarta: Pustaka Pelajar, 1996).

Hanafi, Ahmad, Theologi Islam, (Jakarta: Bulan Bintang, 1989).

Hadiwijono, Harun, Sari Sejarah Filsafat Barat, (Yogyakarta: Kanisius, 1992).

Hitami, Munzir, Mengonsep Kembali Pendidikan Islam, (Pekanbaru: Infinite, 2004). 
Hidayat, Komaruddin, "Manusia dan Proses Penyempurnaan Diri" dalam Budhy-Munawar Rahman (ed). Kontekstualisasi Doktrin Islam dalam Sejarah, (Jakarta: Paramadina, 1995).

Iqbal, Muhammad, The Recontruction of Religiou Thought in Islam, New Delhi: Kitab Bhavan, 1981).

Jalaluddin dan Abdullah Idi, Filsafat Pendidikan, (Jakarta: media pratama, 1997).

Jauhari, Imam Chanafie, Hermeneutika Islam ; Membangun Peradaban Tuban di Pentas Global, (Yogyakarta: Ittaqa Press, 1999).

Kattsoff, L. O., Pengantar Filsafat, (terj), (Yogyakarta: Tiara Wacana, 1987).

Kuntowijoyo, "Krisis Kebudayaan ; Kesenjangan Antara Kesadaran dan Prilaku" dalam Republika, edisi Rabu 16 Desember 1998.

Kartanegara, Mulyadi, Panorama Filsafat Islam. ; Sebuah Refleksi Aoutobiografi, (Bandung: Mizan, 2002).

Muhammad Amin, Mieska, Apistemologi Islam, (Jakarta: UI Press, 1983).

M. Rusli Karim, "Pendidikan Islam di Indonesia Dalam Transformasi Sosial Budaya" dalam Syafi'i Ma'arif dkk, Pendidikan Islam di Indonesia: Antara Cita dan Fakta, (Yogyakarta: Tiara Wacana, 1991).

Nor Wan Daud, Wan Mohd, Filsafat dan Praktik Pendidikan Islam (terj). (Bandung: Mizan, 2003).

Nasr, Sayyed Hussein, Tasawuf Dulu dan Sekarang. (trj) (Jakarta: Pustaka Firdaus, 1991).

,Three Muslim Sages, (Cambridge: Harvard University Press, 1969).
, (ed), Ensiklopedi Tematis ; Spritualitas Islam, (tri), (Bandung: Mizan, 2002).

, Islam ; Antara Cita dan Fakta, (tri). (Yogyakarta: Pusaka, 2001).

, Spritualitas dan Seni Islam, (terj.), (Bandung: Mizan, 1993).

Nasution, Harun, Islam Rasional: Gagasan dan Pemikiran, (Bandung: Mizan, 1995).

Paul Suparno dkk., Reformasi Pendidikan: Sebuah Rekomendasi, (Yogyakarta: Kanisius, 2002).

Roem Topatimasang, Sekolah Itu Candu, (Yokyakarta: Pustaka Pelajar, 1998).

Shimogaki, Kazuo, Kiri Islam Antara Modenisme dan Postmodernisme ; Telaah Kritis atas Pemikiran Hasan Hanafi, (terj.), (Yogyakarta: LkiS, 1993).

Saiyidain, K.G., Iqbal's Education Philosophy, (Lahore: Muhammad asyraf, 1990).

Sudjatmoko, "Pembangunan Sebagai Proses Belajar" dalam Sudjatmoko dkk, Masalah Sosial Budaya Tabun 2000, (Yogyakarta: Tiara Wacana, 1986).

Sindhunata, "Pendidikan Meningkatkan Ketidakadilan" dalam Kompas, No. 07 - 08, Tahun ke-51, Juli - Agustus 2002.

Shadr, Muhammad Baqir, Falsafatuna. (Bandung: Mizan, 1992).

Shihab, M. Quraish, Wawasan al-Qur'an: Tafsir Maudhu'i Atas Berbagai Persoalan Umat, (Bandung: Mizan, 1996).

Syaukani, Omar Muhammad al-Taumi, Falsafah Pendidikan Islam, (terj.). (Jakarta: Bulan Bintang, 1979). 
A1-Fikra: Jurnal Ilmiah Keislaman, Vol. 9, No. 2, Januari-Juni 2010

WM, Abdul Hadi, "Semangat Profetik dalam Sastra Sufi dan Jejaknya dalam Sastra Modern" dalam Horison, no 6, tahun XXII, Juni 1998

Zayyin, Muhammad Husny, Mantiq Ibn Taymiyyah wa Manhayjuh al-Fikr, (Beirut: al-Maktabah al-Islami, 1979). 